\title{
REČNI MEANDRI NA KRAŠKIH POLJIH
}

\author{
Luka Černuta, univ. dipl. geograf \\ Brdo 70, SI-5230 Bovec \\ e-mail: crni.lukc@gmail.com
}

\section{Izvirni znanstveni članek}

COBISS 1.01

\section{Izvleček}

Rečni meandri predstavljajo najpogostejšo tlorisno obliko nižinskih rek. Na (pre)oblikovanje rečnih meandrov na kraških poljih najizraziteje vpliva režim poplavnih voda. Poplave namreč narekujejo prostorsko-časovno conacijo meandrotvornih procesov, od česar zavisi obstoj meandrotvorno aktivne oziroma meandrotvorno pasivne faze razvoja meandrov. Šolski primer meandrov, nastalih zaradi delovanja in součinkovanja preučevanih meandrotvornih procesov, predstavljajo meandri Dobravke na Radenskem polju.

Ključne besede: fizična geografija, geomorfologija, krasoslovje, kraško polje, rečni meandri, fluvialna geomorfologija, Radensko polje, Dobravka

\section{RIVER MEANDERS ON POLJES}

\begin{abstract}
River meanders present the most frequent planform of lowland rivers. Their formation on poljes mostly depends on flood water regime. Flooding dictates space-time zonation of meandering processes, of which the existence of active or passive phase of planform modification depends. Studied meanders of the stream Dobravka on the Radensko polje represent an excellent example of meanders (re)formed by meandering processes (inter)actions.
\end{abstract}

Key words: physical geography, geomorphology, karstology, polje, river meanders, fluvial geomorphology, Radensko polje, Dobravka 


\section{UVOD}

Rečni meandri sodijo med najbolj razpoznavne geomorfne oblike, ki jih ustvarjajo reke. Povečini nastajajo v nižinskem svetu na relativno širokih naplavnih ravnicah. Slovenija ima kljub reliefni razgibanosti dokaj obsežne površine, primerne za nastanek meandrov, vendar je bila večina meandrirajočih vodotokov v povojnem obdobju hidromelioriranih. Različni (obsežnejši) antropogeni posegi so bili sicer načrtovani tudi za nekatera kraška polja, do katerih pa vsaj v večjem obsegu ni prišlo.

\section{I.I. Namen in cilj raziskave}

Osnovni namen raziskave je bil preučiti zakonitosti nastanka in (pre)oblikovanja rečnih meandrov na kraških poljih. Na tej osnovi je bilo postavljenih pet ciljev: ugotoviti vzroke nastanka rečnih meandrov, identificirati procese njihovega (pre)oblikovanja, oceniti dinamiko in razmerja med meandrotvornimi procesi, identificirati ključne dejavnike, ki na te procese vplivajo, in potrditi (ali ovreči) zastavljeno delovno hipotezo.

\section{I.2. Delovna hipoteza}

Na osnovi splošnih spoznanj velja trditev, da je rečne meandre izoblikovala tekoča rečna voda. Iz te je bila izpeljana tudi delovna hipoteza, ki se glasi: rečni meandri so geomorfne oblike, nastale kot posledica delovanja tekoče rečne vode.

\section{I.3. Metode dela}

Tekom raziskave sta sočasno potekala oba načina preučevanja - induktivni in deduktivni. Tovrstni pristop se je izkazal za koristnega, saj se je nemalokrat zgodilo, da je bil terenski ogled povod za teoretično preučitev videnega, na drugi strani pa je tudi študij literature omogočil spoznavanja na terenu, ki bi sicer lahko ostala neopažena.

V sklopu kabinetnega dela sem v prvi vrsti pregledal in preučil obstoječo znanstveno literaturo. V večini primerov so bili to znanstveni članki znanstveno-informacijskega servisa ScienceDirect in nekaterih drugih, javno dostopnih internetnih strani ter prispevki, objavljeni v različnih geomorfoloških zbornikih in monografijah. Za analize prostorskih podatkov sem uporabljal GIS orodja ArcMap, Global Mapper in Idrisi.

Glavnino terenskega dela je predstavljalo spremljanje in opazovanje procesov v pokrajini. To je potekalo kot namensko in kot nenamensko opazovanje. Namensko sem iskal določene pokazatelje, ki bi potrdili ali ovrgli ugotovitve, zapisane v literaturi. V primeru nenamenskega pa je šlo za celovito opazovanje dogajanja v pokrajini, kar je privedlo do posameznih zamisli, katere je bilo kasneje potrebno ovrednotiti. Poleg opazovanja so bile izvedene tudi tri vrste (morfoloških) meritev: širine struge, globine struge in naklonov rečnih brežin. 


\section{I.4. Dosedanja preučevanja}

V svetovni literaturi je rečne meandre raziskovala množica avtorjev različnih strok. V Sloveniji je drugače, saj je rečnim meandrom posvečeno zelo malo pozornosti. Za raziskave rečnih meandrov na kraških poljih pa to velja tudi v svetovnem merilu.

\section{SPLOŠNO O OSNOVNIH FLUVIOGEOMORFNIH PROCESIH}

S terminom fluvialni (geomorfni) procesi so označeni snovno-energijski pretoki po strugi vodotoka oziroma znotraj rečnega koridorja. Glavni dejavnik geomorfnega delovanja tekoče rečne vode je strugotvorni pretok. To je pretok, ki teče skozi mokri profil in zapolnjuje strugo vodotoka do višine, ko se voda začne prelivati preko brežin (Bizjak 2003). Razpoložljiva energija, ki jo vodotok porablja na svoji poti za opravljanje dela, se v prvi vrsti troši za lastni tok, t.j. za premagovanje viskoznosti in turbulentnosti oziroma notranjega trenja tekočine ter za premagovanje trenja s podlago. Presežek energije vodnega toka se nato porabi za transport $v$ toku vsebovanih plavin in nazadnje še za erozijsko delovanje (Natek 2003; Knighton 1998). Potek fluviogeomorfnih procesov je $\mathrm{v}$ veliki meri odvisen od značilnosti vodnega toka in gradiva $v$ rečnem koritu (Thorne 1997).

V sklop rečne erozije se uvrščajo tako procesi mehaničnega kot kemičnega odnašanja. Odnašanje poteka s hidravlično silo, $\mathrm{z}$ abrazijo transportiranega gradiva in s korozijo (Bizjak 2003). Glede na smer delovanja rečne erozije se razlikujeta globinska in bočna erozija. Pri globinski eroziji prihaja do poglabljanja struge (v lastne nanose ali živoskalno podlago), $\mathrm{v}$ primeru bočne erozije pa se vodotok zajeda $\mathrm{v}$ rečne brežine, kar povzroča bočno premikanje brežin (Geografija 2001; Natek 2003).

Način oziroma oblika transporta plavin je odvisna od velikosti delcev in intenzitete vodnega toka (Robert 2003). Gradivo v rečni strugi se prenaša $\mathrm{z}$ rinjenjem, kotaljenjem, poskakovanjem, lebdenjem in v raztopini (Knighton 1998; Bizjak 2003; Mikoš 2000; Natek 2003). $\mathrm{Z}$ drsenjem in kotaljenjem (prod) ali poskakovanjem (pesek) se po dnu struge (oz. v njegovi neposredni bližini) premeščajo rinjene plavine (Bizjak 2003; Knighton 1998; Mikoš 2000; Mikoš in sod. 2002; Robert 2003). Poskakovanje predstavlja vmesno stopnjo med premeščanjem rinjenih in lebdečih plavin (Mikoš 2000; Robert 2003). Lebdeče plavine so plavine finejših (meljasto-glinastih) frakcij, ki se prenašajo v suspenziji s podobnimi hitrostmi kot tok. Transport gradiva v raztopini nima (večjega) vpliva na morfološko preoblikovanje vodotokov.

Sedimentacija plavin v vodotoku se začne, ko hitrosti vodnega toka padejo pod umiritveno hitrost, ki je za posamezne frakcije različna. V primeru gradiva večjih frakcij so umiritvene hitrosti le za drobec manjše od kritičnih erozijskih hitrosti, pri najmanjših frakcijah pa se te močno razlikujejo (Knighton 1998). Tako kot pri eroziji in transportu se lahko tudi v primeru sedimentacije zaradi različnih vzrokov pojavlja 'nelinearnost' v poteku procesa. Do takšne modifikacije splošnega vzorca usedanja na primer prihaja pri posedanju skupine (oblaka) zrn (Mikoš 2000). 
Po sedimentaciji je gradivo podvrženo različnim kemično-fizikalnim oblikam preobražanja, ki olajšujejo ali otežujejo nadaljnje cikluse fluviogeomorfnih procesov.

\section{TLORISNA OBIKA STRUG(E)}

Meandrirajoče struge predstavljajo enega izmed tipov tlorisnih oblik strug(e). Za začetnika preučevanj tlorisnih oblik veljata Leopold in Wolman (1957), s to tematiko pa se je poleg njiju ukvarjala še kopica drugih avtorjev. V nadaljevanju so predstavljene štiri najpogostejše tlorisne oblike: utesnjene in meandrirajoče ter pramenaste in anastomozne. Prvi dve spadata med enojne, drugi dve pa med deljene tlorisne oblike struge. Utesnjene in pramenaste se pojavljajo pretežno $\mathrm{v}$ povirnih, gorskih odsekih rečnih dolin, meandrirajoče in anastomozne pa na obsežnih poplavnih ravnicah, bliže rečnim ustjem.

\section{I. Utesnjene struge}

V skupino (alohtono) utesnjenih strug sodijo predvsem hudourniki in gorski potoki, za katere so značilni strmi nakloni in velika prodonosnost. Utesnjene struge izoblikujejo visokoenergijski in orografsko (alohtono) omejeni, lateralno stabilni vodotoki (Fluvial hydrosystems 1996; Beechie in sod. 2006). Večji del energije tovrstnih vodotokov se s procesom globinske erozije porablja za glajenje 'anomalij' v podolžnem profilu vodotoka, ki so povečini izražene v obliki kaskad in stopenj oziroma slapov (Rosgen 1994; Fluvial hydrosystems 1996). Naplavne ravnice teh vodotokov naj ne bi bile širše od štirikratne strugotvorne širine struge vodotoka, to je širine, ki omogoča nastanek ostalih tlorisnih oblik (Beechie in sod. 2006).

\subsection{Pramenaste struge}

Pramenaste struge so tisti odseki vodotokov, kjer se struge v 'pramenih' vijejo med prodišči(Natek 2003). Reke s takim tlorisnim tipom so v preteklosti označevali kot 'podivjane' (Mikoš 2000). Pojavnost pramenastih vodotokov je v tesni povezavi z zgoraj opisanimi (alohtono) utesnjenimi strugami, saj se tudi te pojavljajo predvsem na odsekih z veliko reliefno energijo. Najpogostejše so na (strmejših) naplavnih ravnicah in vršajih (Chorley in sod. 1984). Za nastanek pramenastih strug ni brezpogojno potrebna široka naplavna ravnica, saj v odvisnosti od pretoka prihaja med (alohtono) utesnjenimi in pramenastimi strugami pogosto do medsebojne (začasne) preobrazbe. Medtem ko se v obdobju srednjih in nizkih pretokov struge med številnimi mobilnimi prodišči delijo in ponovno združujejo (Mikoš 2000; Bizjak 2003; Repnik 2006), so prodišča ob višjih, a še vedno strugotvornih pretokih pogosto preplavljena, tako da struga dobi videz enojne, bolj ali manj 'izravnane' struge (Knighton 1998).

\subsection{Meandrirajoče struge}

Meandri oziroma okljuki so zankam podobni rečni zavoji, ki jih vodni tok dela ob majhnem strmcu. Ime so dobili po antični reki Meander, danes imenovani Büyük Menderes v Mali Aziji (Natek 2003). Ustrezneje kot o meandrirajočih strugah bi bilo govoriti o 
vijugajočih strugah, saj prvo omenjeni izraz poudarja enakomernost, simetričnost, drugi pa nerednost, asimetričnost. Poleg 'klasičnih', t.i. prostih meandrov, gre omeniti še t.i. ujete meandre, ki nastanejo ob sočasnem tektonskem dvigovanju ozemlja in hkratnem erozijskem vrezovanju v živoskalno podlago, v katero se ‘ujamejo' (Natek 2003; Geografija 2001). Več o menadrirajočih strugah bo povedano v osrednjem (5.) poglavju pričujočega članka.

\subsection{Anastomozne struge}

Anastomozne reke oziroma rečni odseki so tako kot pramenaste sestavljene iz več delnih strug (Alvarez 2005). To so nizkoenergijski vodotoki s povezano mrežo posameznih, lokalno močno sinusoidnih strug (Ritter in sod. 1995; Fluvial hydrosystems 1996). Podobnost pramenastih in anastomoznih vodotokov je le v tem, da se enotne struge razcepijo oziroma razdelijo v dve ali več manjših delnih strug, procesi nastanka obojih pa so precej različni (Fluvial hydrosystems 1996; Rosgen 1994). Do formiranja anastomoz najpogosteje prihaja na območju delt, kjer so anastomozne struge najbolj značilne tlorisne oblike. Na območju delte, kjer pri formiranju anastomoz ne pride več do zadnjega koraka - ponovne združitve strug, bi se lahko govorilo o dendritični tlorisni obliki, ki zaznamuje deltino čelo in ji daje značilno pahljačasto obliko.

Slika 1: Alohtono utesnjena struga reke Koritnice (zgoraj levo), pramenasta struga reke Tilment (zgoraj desno), meandrirajoča struga reke Wampoolv severni Angliji (spodaj levo) in anastomozna struga v narodnem parku Everglades (spodaj desno)

Figure 1: Allochthonously confined channel of the river Koritnica (top left), braided channel of the river Tilment (top right), meandering channel of the river Wampool in northern England (bottom left) and anastomosing channel in Everglades National Park (bottom right)
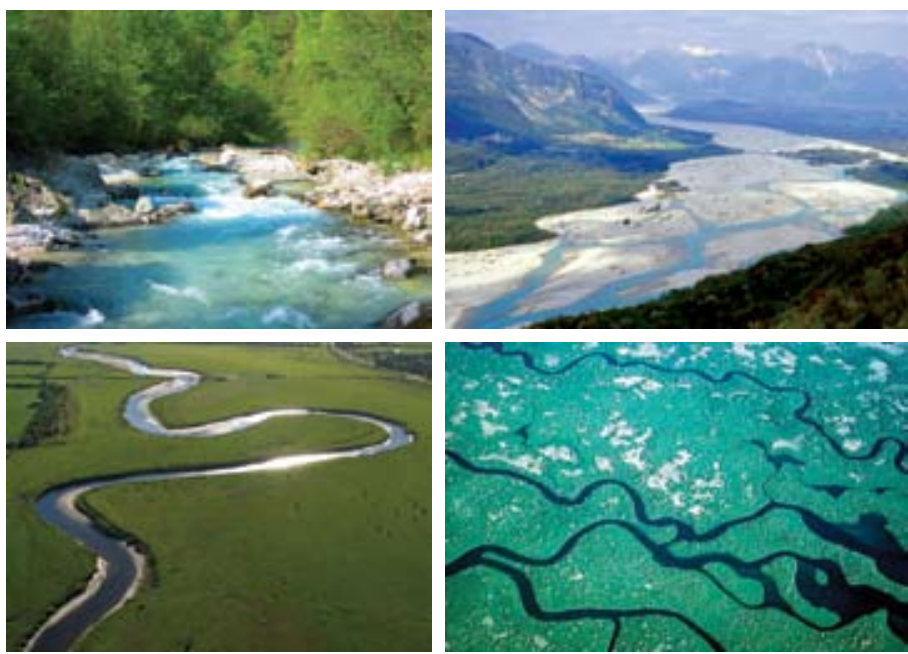

Viri/Sources: L. Černuta; Rumore bianco 2009; Meandering River Wampool 2008; Earth Science World Image Bank 2008 


\section{TEORETIČNA ANALIZA MEANDRIRAJOČIH VODOTOKOV}

\section{I. Osnovne lastnosti meandrirajočih vodotokov}

S tlorisnega vidika predstavlja rečni meander zaporedje dvojice rečnih zavojev vzdolž dolinske osi (X), oziroma vzdolž (povprečne) dolvodne smeri vodotoka. Rečni zavoj je odsek meandra med dvema prevojema meandra in torej obsega polovico samega meandra (Julien 2002).

Slika 2: Temeljne tlorisno-morfološke značilnosti meandrirajočega vodotoka

Figure 2: Basic planform characteristics of the meandering stream

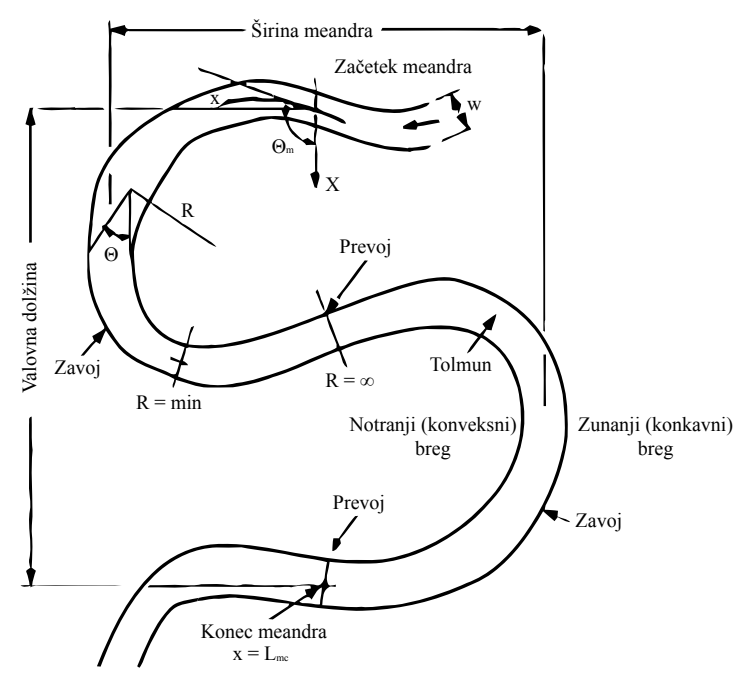

Vir/Source: Julien 2002

Vzdolžna dimenzija meandra je ponavadi označena z dejansko dolžino struge $L_{m c}$ in $\mathrm{z}$ valovno dolžino meandra $(\lambda)$, razmerje med prvo in drugo pa predstavlja temeljno karakteristično število meandrirajočih vodotokov - sinusoidnost $(\psi)$.

$$
\psi=\frac{L_{m c}}{\lambda}[-]
$$

Lateralna dimenzija meandrov je najpogosteje opisana s širino ali z amplitudo meandra. Pomemben karakteristični podatek tlorisne izoblikovanosti vodotoka je tudi t.i. krivinski polmer (R). Krivinski polmer v kombinaciji s širino struge (w) tvori brezdimenzijsko razmerje (R/w), ki izraža ostrino zavoja. Manjše kot je omenjeno razmerje, večja je zakrivljenost zavoja meandra. Poleg značilne vijugaste tlorisne izoblikovanosti imajo meandrirajoči vodotoki 
tudi značilen prečni prerez. Meandrirajoči vodotoki, tekoči v vezljivih naplavinah, imajo ponavadi globoke in ozke struge (Ritter in sod. 1995; Rosgen 1994). Prečni prerezi rečnega korita so najpogosteje parabolične (Mikoš 2000), v zavojih lahko močno asimetrične oblike (Robert 2003).

Vzroke za nastanek meandrov obravnava več različnih teorij. Nekatere se razlikujejo le v podrobnostih, druge pa so si celo diametralno nasprotne. Takšni sta t.i. disipacijska teorija ('teorija o namenskem podaljševanju struge') in t.i. redukcijska teorija ('teorija o nenamenskem podaljševanju struge'). Pri prvi gre za težnjo po porabi 'odvečne' energije, pri drugi pa za zmanjševanje izgub energije vodnega toka. Zmanjšanje moči vodnega toka je torej lahko rezultat meandriranja, lahko pa je tudi vzrok nastanka le-tega (Alvarez 2005). Perturbacijska teorija kot najpomembnejši vzrok nastanka meandrov poudarja različne pokrajinske 'anomalije', nahajajoče se na naplavni ravnici (npr. reliefne ovire, vegetacijo, antropogene objekte; Alvarez 2005; Thorne 1997). 'Anomalije' imajo pri nastajanju meandrov lahko tako pozitivno kot tudi negativno vlogo, saj lahko njihov razvoj pospešujejo ali omejujejo (Julien 2002; Knighton 1998). Ker pa hidrodinamika v osnovi temelji na empirično potrjenih fizikalnih načelih o ohranitvi mase, energije in gibalne količine (Plazl 2008), ki predstavljajo primarni faktor vseh fluviogeomorfnih procesov, je osnovna teorija nastajanja meandrov t.i. preservacijska teorija. Ohranitev gibalne količine povzroča, da vodni tok in posledično vodotok na mikro ravni stalno teži k ohranitvi prvotne smeri (težnja po izravnavi mikro odseka). Posledica tovrstne težnje pa je vse večje vijuganje na 'makro' nivoju (Likar 1999).

Za energijsko najučinkovitejšo tlorisno izoblikovanost meandrov naj bi veljala t.i. 'trigonometrirana tlorisna izoblikovanost'. Pri tej izoblikovanosti se odklonski kot vodotoka spreminja na način kot ga opisuje 'sinusoida', torej sorazmerno s sinusno oziroma kosinusno vrednostjo dolžinskega deleža $\left(x / L_{m c}\right)$.

$$
\theta=\theta_{m} \cos \frac{2 \pi x}{L_{m c}} \quad[\mathrm{rad}]
$$

Odklonski kot $\theta$ na določeni oddaljenosti od začetka rečnega odseka je tako funkcija maksimalnega odklonskega kota $\theta_{m}$ in razmerja med to oddaljenostjo $(x)$ ter celotno dolžino meandra $\left(L_{m c}\right)$ (Langbein in Lepold 1966; Adam 2006; Julien 2002; Knighton 1998).

Povezanost vrednosti maksimalnega odklonskega kota zavoja meandra s sinusoidnostjo vodotoka prikazuje spodnja enačba (Langbein in Lepold 1966).

$$
\theta_{m}=2,2 \sqrt{\frac{\psi-1}{\psi}} \quad[\mathrm{rad}]
$$

Zaradi dejstva, da maksimalni odklonski kot zavoja meandra na idealni('brezanomalijski’) naplavni ravnici ne more preseči $90^{\circ}$, gre iz izpeljave zgornje enačbe sklepati, da sinusoidnost posamičnih (trigonometriranih) meandrov ne presega vrednosti $\sim 2$. 
Slika 3: Primerjava tlorisne izoblikovanosti vodotoka $v$ naravi (zgoraj) in spreminjanje odklonskega kota $v$ odvisnosti od dolvodne razdalje (spodaj)

Figure 3: Comparison of planform morphology of the stream in nature (above) and the change of orientation angle as a function of downstream distance (bottom)
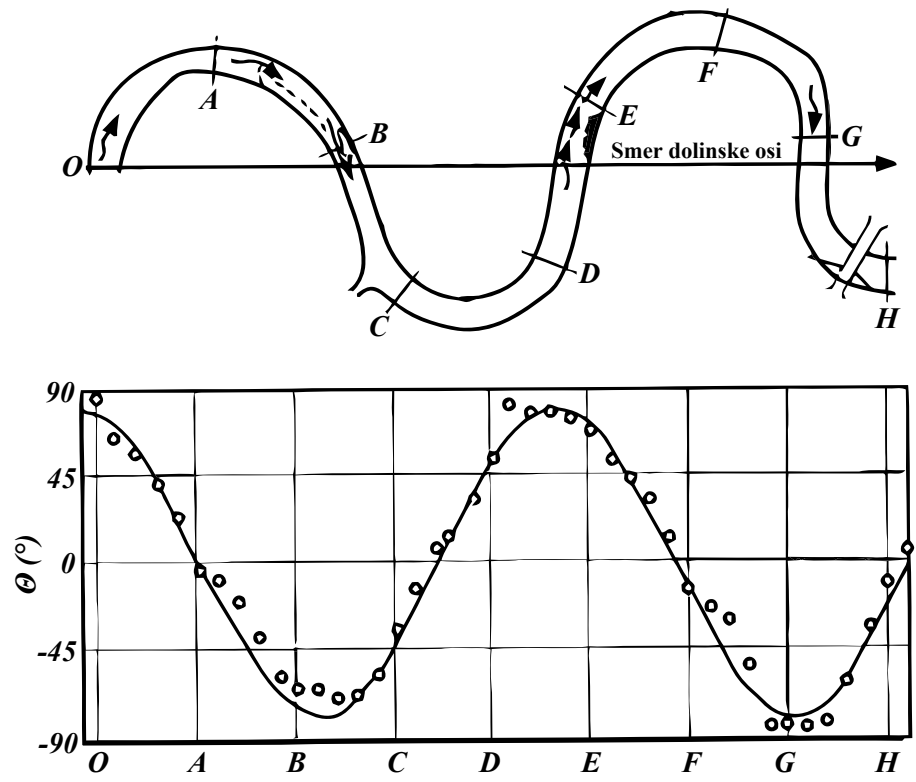

Vir/Source: Julien 2002

\subsection{Temeljne značilnosti naplavin na kraških poljih}

Dna kraških polj v pretežni meri, še zlasti pa v zgornjih naplavinskih plasteh, sestavljajo vezljive naplavine, s posameznimi delci velikostnega reda melja in gline. Pri gradivu, manjšem od 0,01 mm, prihaja v naplavinah do pojava kohezije (Mikoš 2000), oziroma adhezije. Jakost adhezijskih in kohezijskih sil je za strugotvorne procese ključnega pomena, saj neposredno od njih zavisi odpornost vezljivih naplavin oziroma njihova erodibilnost.

Poleg velikostne sestave naplavljenega gradiva (teksture), je pomemben tudi način medsebojnega povezovanja posameznih zrn v večje skupke (struktura naplavin). Strukturni agregati se kot tridimenzionalna telesa ločujejo po obliki, velikosti in obstojnosti (Lovrenčak 1994; Suhadolc in sod. 2006). V naplavinah na kraških poljih se najpogosteje pojavljajo predvsem prizmatični in lističasti strukturni skupki.

Eden izmed najpomembnejših dejavnikov, ki vpliva na lastnosti vezljivih naplavin, je tudi njihova mineralna sestava. Minerali glin (kaolinit, montmorilonit, ilit...) imajo namreč različne lastnosti, s katerimi pomembno vplivajo na ostale 'makro' lastnosti naplavin. Med lastnostmi mineralov glin je pomembna predvsem dovzetnost za vezavo vode in ionov ter posledično nabrekanje oz. krčenje. 
Erodibilnost vezljivih naplavin je močno odvisna tudi od poroznosti le-teh. Prisotnost vode (in/ali zraka) v naplavinah namreč zavisi od vrste, predvsem pa od velikosti por. V vezljivih naplavinah nastajajo povečini mikropore $(<10 \mu \mathrm{m})$, tako da v njih prevladuje kapilarna voda (Suhadolc in sod. 2006; Lovrenčak 1994). Poleg te je pomembna tudi 'negibljiva' higroskopska voda (Lovrenčak 1994), ki se pojavlja v obliki tanke plasti molekul okrog posameznih naplavinskih delcev. Razen omenjenih imajo tudi ostale oblike vode (npr. kemična voda ali led) močan vpliv na meandrotvorne procese, opisane v naslednjem poglavju.

\subsection{Meandrotvorni procesi}

\subsection{Procesi odnašanja vezljivih naplavin}

V sklop procesov odnašanja uvrščamo fluvialno erozijo rečnega korita in denudacijo rečnih brežin. Delitev na osnovi dominantne smeri delovanja (odnašanja) je narejena zgolj zavoljo pravilnejše ocene dinamike meandrotvornih procesov, saj ti procesi v naravi delujejo vzajemno. V primeru fluvialne erozije prevladuje dolvodna smer (vzdolž struge) odnašanja gradiva, pri denudaciji pa prihaja do odnašanja brežinskega gradiva prečno na strugo (brežino).

Fluvialna erozija vezljivih naplavin se od erozije v prodonosnih vodotokih močno razlikuje. Medtem ko pri nevezljivih sedimentih prihaja do premikov posameznih zrn, je odnašanje vezljivih sedimentov bistveno drugačno, predvsem pa kompleksnejše (Julian in Torres 2006). Posamezni delci naplavine so zaradi kohezijskih in adhezijskih sil ter njihove majhnosti zelo redko neposredno erodirani. Večina erozije vezljivih naplavin se tako odvija v obliki erozije naplavinskih agregatov (Julian in Torres 2006; Robert 2003; Knighton 1998).

Ker je (meandrirajoča) rečna struga v prvi vrsti vdolbina, nastala zaradi vrezovanja tekoče vode, se kot inicialni strugotvorni proces pojmuje globinsko erozijo. Ta je (bila) kot fluviogeomorfni proces na naplavni ravnici kraških polj prisotna v dveh temeljnih oblikah, tj. kot inicialna in kot recentna globinska erozija. Primarna oziroma inicialna globinska erozija je nekakšen paleofluviogeomorfni proces, s katerim so se na nastalih kraških poljih $\mathrm{z}$ vrezovanjem vodnega toka $\mathrm{v}$ naplavno ravnico izoblikovale prvotne struge vodotokov. Recentna globinska erozija je v primerjavi z inicialno globinsko erozijo, predvsem pa $\mathrm{v}$ primerjavi z (recentno) bočno erozijo, za nastajanje meandrov na kraških vodotokih manj pomembna, saj se dno kraških polj nahaja na višini relativne (lokalne) erozijske baze. Zaradi tega dejstva je recentna globinska erozija v klasičnem pomenu relativno nepomembna. Dokaj intenzivna ostaja le t.i. globinsko-notranja oziroma interna erozija. Gre za proces spiranja naplavinskega gradiva v kraško notranjost, ki je najizrazitejši v bližini ponorov.

Za preoblikovanje meandrov je najpomembnejša bočna erozija, pri kateri prihaja do erozije rečnih bregov, povečini na zunanjih delih zavojev. Poleg prostorsko-časovnega spreminjanja erozivnosti (moči) vodnega toka, je prostorska spremenljivost bočne erozije odvisna tudi od prostorske spremenljivosti erodibilnosti brežinskega gradiva (Ritter in sod. 1995; Robert 2003).

V zavojih so tokovnice pod vplivom (navidezne) centrifugalne sile, zaradi česar se premaknejo k zunanji brežini. Ob zunanjem bregu posledično prihaja do dviga, ob notranjem pa 
do znižanja vodne gladine (Steinman 1999; Robert 2003; Ritter in sod. 1995; Mikoš 2000). Tovrstni učinek je izražen predvsem v primeru ostrih zavojev in zadovoljive hitrosti vodnega toka (Steinman 1999). Prihaja do sekundarnega toka, ki je v slojih vodne mase blizu površja usmerjen proti zunanjemu bregu, v bližini dna pa proti notranjemu bregu (Robert 2003). Ker prihaja v vodnem toku med sekundarno cirkulacijo in ponavadi dominantnejšo dolvodno komponento vodnega toka do součinkovanja, nastane t.i. spiralast vodni tok (Knighton 1998).

Slika 4: Spiralna cirkulacija vodnega toka vzdolž meandra

Figure 4: Spiral flow along the meander

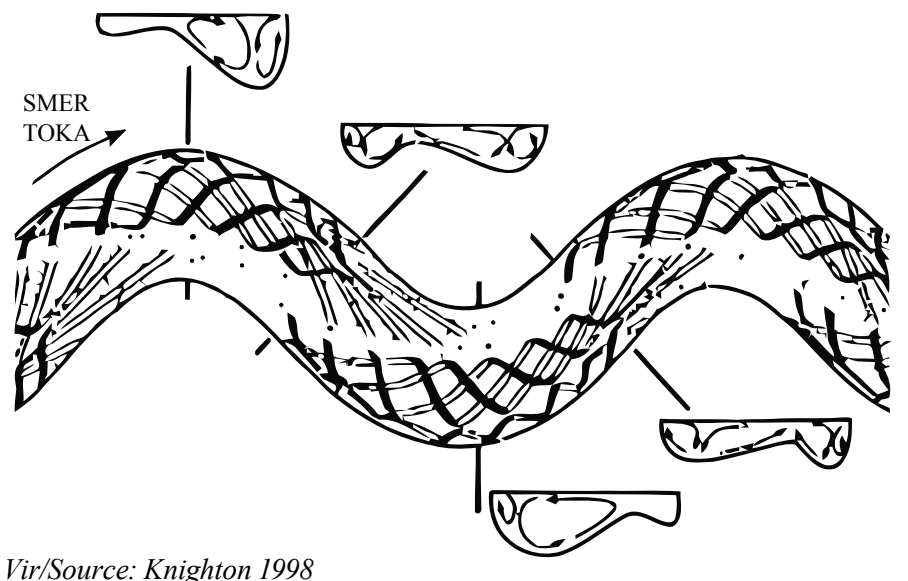

Posledica prostorsko-časovne spremenljivosti erozije in sedimentacije se kaže v tlorisnomorfološki modifikaciji meandrirajočih vodotokov. Najpogosteje razlikujemo tri temeljne tipe tlorisno-morfološke modifikacije: rast, migracijo in preboj. S pojmom rast meandra se označuje predvsem širjenje loka posameznega zavoja meandra v pravokotni smeri na dolinsko os, kar posledično povečuje amplitudo meandra in njegovo sinusoidnost. V okviru rasti se ločuje dve vrsti: ekstenzija in neenakomerna rast. Pri migraciji meandra je prevladujoča dolvodna komponenta premika. Povzroči jo intenzivna erozija, delujoča vzdolž dolinske osi, ki je najintenzivnejša na temenu zavoja oziroma nekoliko pod njim. Tudi v primeru migracije sta poznani dve (temeljni) obliki: translacija in rotacija (Thorne 1997).

Slika 5: Primera rasti (A) in migracije (B) zavoja meandra

Figure 5: Examples of meander growth (A) and meander shift (migration) (B)

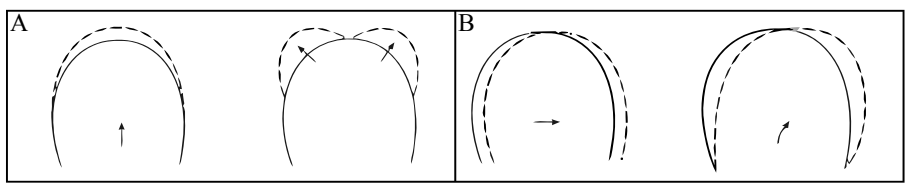

Vir/Source: Knighton 1998 
Zaradi prekomerne sinusoidnosti (razvitosti) meandrov prihaja pogosto do prebojev posameznih zavojev, ki so ponavadi posledica kombinacije intenzivne rasti in migracije meandrov. Značilni sta dve temeljni vrsti: erozijski in prelivni preboj. Dejstvo, da je za nastanek preboja potrebna visoka sinusoidnost, velja predvsem za erozijski preboj, medtem ko v primeru prelivnega preboja ta ni nujno potrebna (Julien 2002).

Slika 6: Prelivni (levo) in erozijski (desno) preboj

Figure 6: Cut-off through overflow (left) and neck cut-off (right)

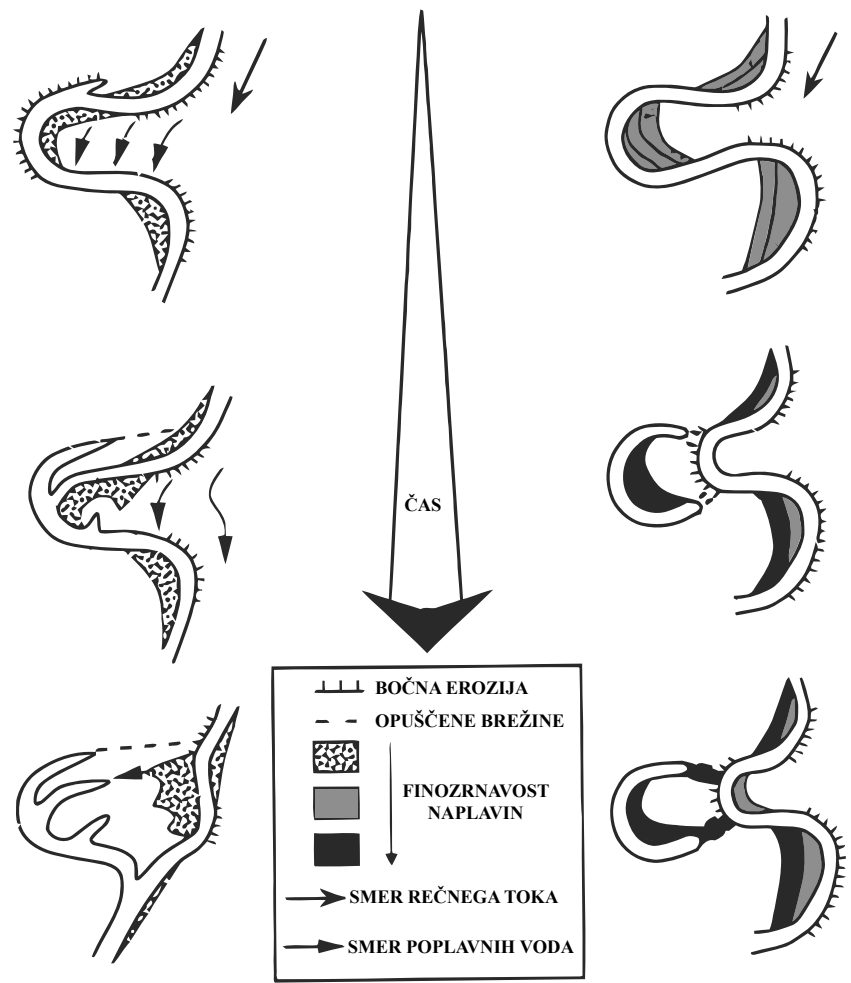

Vir/Source: Fluvial hydrosystems 1996

Na območju erozijskega ali prelivnega preboja se vzpostavi nova struga, na mestu stare pa nastane mrtvi rokav, mrtvica, ki je fluviogeomorfno pogojno aktivna le v času poplav. Med poplavami prihaja do nadaljnje sedimentacije in nastajanja vse plitvejše močvirnate kotanje. Tudi v zaključni fazi, ko je nekdanji zavoj meandra $\mathrm{z}$ naplavinami povsem zapolnjen, je v pokrajini še vedno viden, saj so za mrtvico značilni drugačni rastni pogoji in pripadajoča hidromorfna vegetacija (Ahnert 1996).

Kot je bilo že v uvodu v to poglavje omenjeno, so procesi denudacije rečnih brežin neločljivo povezani s fluvialno erozijo (in obratno). Da pride do denudacije brežin, morajo biti 
te zadovoljivo strme in bolj ali manj nestabilne. Takšno morfologijo brežin pa ohranja le dovolj intenzivna fluvialna erozija. V tem poglavju bodo predstavljeni nefluvialni razlogi za denudacijo rečnih brežin, ki je lahko subaerialno ali pluvialno pogojena.

Subaerialni procesi so rezultat mikroklime naplavin, vključujoč tako vlažnostne kot temperaturne razmere naplavin (Wynn in sod. 2007; Thorne 1997; Couper 2003). Najintenzivnejši so v vezljivih naplavinah, znotraj katerih prihaja zaradi vpliva mikroklimatskih dejavnikov do slabljenja adhezijskih in kohezijskih sil (Suhadolc in sod. 2005). Na ta proces so posebej občutljive naplavine z meljasto-glinastim deležem, večjim od 20 \% (Couper 2003).

$\mathrm{V}$ primeru prekomerne vsebnosti vode (t.i. saturacijsko pogojeni subaerialni procesi) se vezljivim naplavinam njihove mehanske značilnosti močno poslabšajo, zaradi česar lahko pride do zdrsa brežine ali pa celo do pojava likvefakcije same naplavine (Wynn in sod. 2007; Rusjan in Mikoš 2006; Thorne 1997). Najpogosteje se zdrsi brežin, sestavljenih iz vezljivih naplavin, pojavljajo v obliki rotacijskega ali translacijskega zdrsa (Knighton 1998). Za rotacijski zdrs je značilna (pol)krožna, za translacijski zdrs pa ravna drsna ploskev.

Slika 7: Rotacijski zdrs (levo) spodnjega dela in translacijski zdrs (desno) zgornjega dela brežine (foto: L. Černuta)

Figure 7: Rotational bank failure (left) of the lower part and translational bank failure (right) of the upper part of the stream bank (photo: L. Černuta)
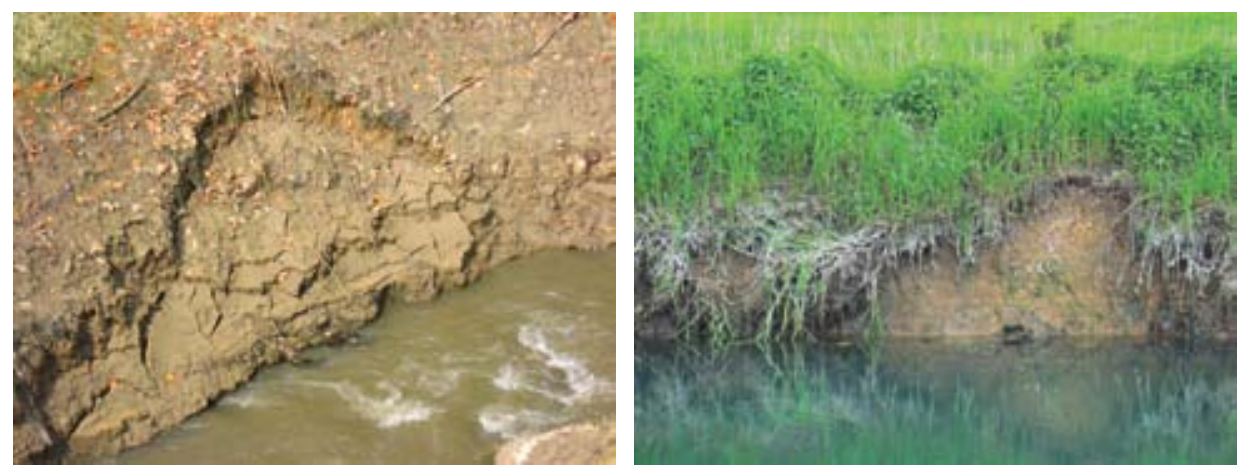

Pri pomanjkanju vode (t.i. aridno pogojeni subaerialni procesi) prihaja $v$ vezljivih naplavinah do krčenja, zaradi česar v zgornjih (površinskih) naplavinskih plasteh nastajajo razpoke (Couper 2003; Thorne 1997; Suhadolc in sod. 2005). Razpad in odnašanje gradiva $z$ brežin poteka na dva načina. $V$ prvem primeru prihaja do nastanka naplavinskih agregatov (velikost 1-3 mm) in njihove (neposredne) denudacije ob vznožje brežin (Thorne 1997; Couper 2003). V drugem primeru pa gre za luščenje (plastenje) površinskih plasti gradiva na brežinah, ki se z zvijanjem plasti formirajo v bolj ali manj zaokrožene delce (ploskve; Hrovat 1953). Te nestabilne, še nedenudirane dele brežine rečna voda (fluvialna erozija) mnogo lažje odnese, kot bi jih v primeru zbitih naplavin (Thorne 1997). 
Slika 8: Posledice aridno pogojenih subaerialnih procesov (foto: L. Černuta)

Figure 8: Results of subaerial processes caused by drying of the alluvial clay surface (photo: L. Cernuta)
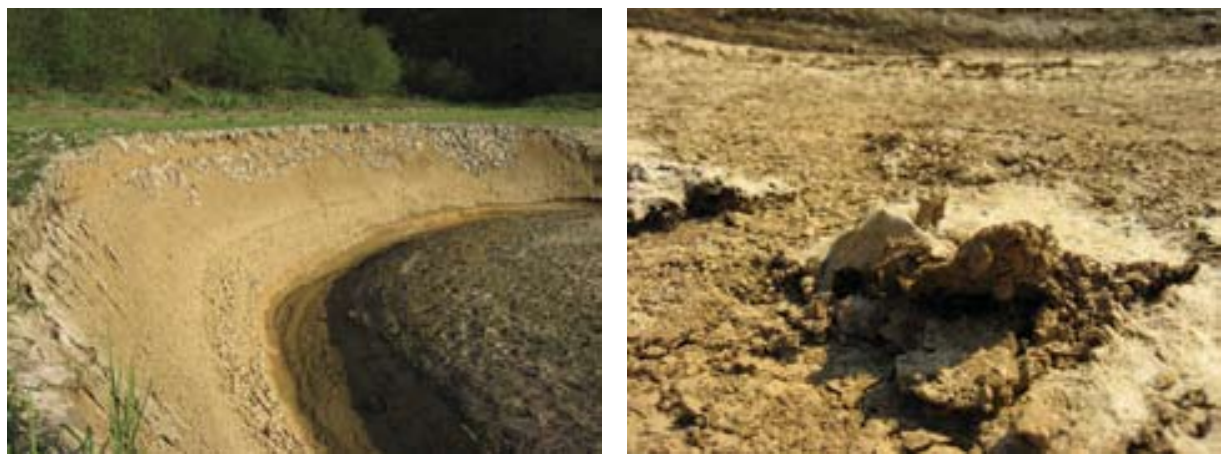

Prisotnost vode in njeno agregatno stanje sta pomembna tudi v primeru t.i. temperaturno pogojenih subaerialnih procesov. Ti procesi se aktivirajo, ko v (prekomerno) vlažnih vezljivih naplavinah in ob negativnih temperaturah prihaja do sočasnega in obsežnejšega zmrzovanja naplavinske mase. Takrat namreč leče ledu razkoljejo in razrahljajo s kohezijo povezane delce (Thorne 1997). Razpad oziroma nastanek naplavinskih agregatov je torej $\mathrm{v}$ primeru temperaturno pogojenih subaerialnih procesov ravno obraten kot $\mathrm{v}$ primeru aridno pogojenih subaerialnih procesov, posledice delovanja tako enih kot drugih pa so si precej podobne. Intenziteta razpadanja skupkov in njihova velikost zavisi od števila ponovljenih ciklov zmrzovanja in tajanja. Bistveno zmanjšanje stabilnosti skupkov in posledično povečana intenziteta razpadanja le-teh nastopi po 5-ih do 10-ih ponovljenih ciklih zmrzovanja in tajanja. Tako je največja intenzivnost razpadanja ponavadi v pozni zimi in zgodnji pomladi (Wynn in sod. 2007; Thorne 1997).

Slika 9: Posledice temperaturno pogojenih subaerialnih procesov (foto: L. Černuta) Figure 9: Results of subaerial processes caused by freeze-thaw effect (photo: L. Černuta)
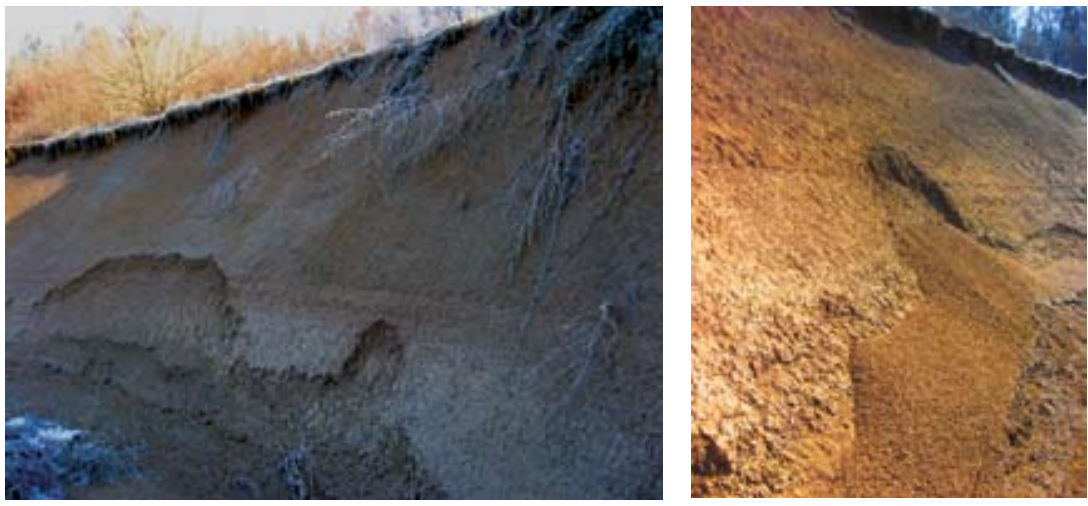
Poleg subaerialno pogojene prihaja tudi do pluvialno pogojene denudacije. V okviru meandrotvornih procesov kraških vodotokov sta pomembni predvsem pljuskovna in ploskovna erozija, redkeje tudi žlebična erozija, notranja erozija pa je bolj ali manj zanemarljiva. Pljuskovna erozija je najintenzivnejša v začetku padavinskega dogodka, saj takrat ponavadi še ni aktiviran ploskovni odtok. Podobno velja tudi za notranjo erozijo. Zasičenost naplavin z vodo in nadaljevanje padavinskega dogodka sta pobudnika ploskovne erozije. Ta v nadaljevanju v skrajnem primeru poteka samostojno, saj postane ob morebitni preobilici padavin sloj ploskovno odtekajoče vode tako debel, da preprečuje pljuskovno erozijo. $\mathrm{V}$ večini primerov pa temu ni tako, zato procesa pljuskovne in ploskovne erozije običajno potekata sinhrono.

Slika 10: Posledice žlebične (in ploskovne) erozije (foto: L. Černuta)

Figure 10: Results of rill (and sheet) erosion (photo: L. Černuta)

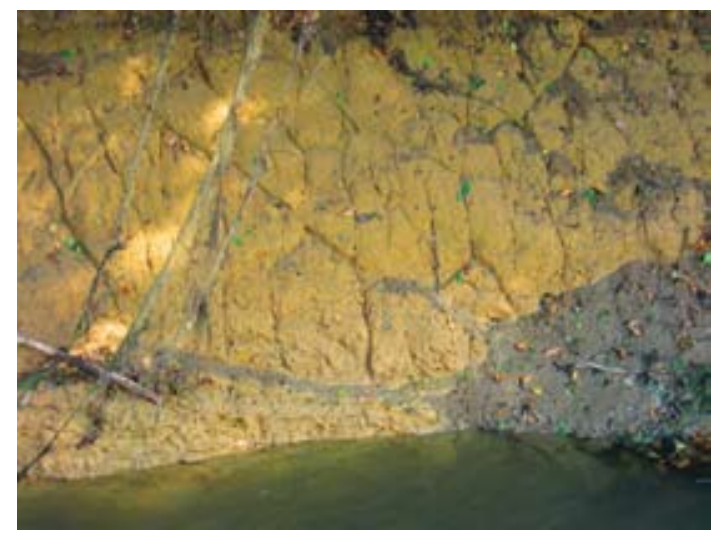

\subsubsection{Transport in sedimentacija vezljivih lebdečih plavin}

Transport lebdečih vezljivih plavin nima neposrednega vpliva na morfologijo vodotoka. Kljub temu predstavlja pomemben povezovalni mehanizem med erozijo na eni in sedimentacijo na drugi strani. Sočasno s transportom potekajo procesi agregacije oziroma flokulacije plavine (Krishnappan in Marsalek 2002; Nakagawa in Zhang 2004). Flokulacija je proces združevanja koloidnih delcev v flokule oziroma kosme. Zrna se agregirajo zaradi medsebojnih trkov posameznih delcev in medsebojno privlačnih sil elektrokemičnega izvora (Liu in sod. 2002; Kranenburg 1999). Nastali kosmi so v primerjavi z individualnimi delci relativno veliki in porozni (Erosion, transport ... 2008; Bungartz in sod. 2001). Nadaljnje formiranje agregatov $\mathrm{v}$ bolj kompaktno formo se opisuje s terminom koagulacija. Medtem ko je flokulacija v kombinaciji s procesom deflokulacije reverzibilen proces, pa koagulacija predstavlja ireverzibilni proces (Aggregation, flocculation and coagulation 2008). Transport vezljivih plavin, ki torej poteka povečini v obliki kosmov (Thorne 1997), se prekine, ko transportna kompetenca in kapaciteta padeta pod mejno vrednost, oziroma ko hitrosti vodnega toka padejo pod umiritveno hitrost. 
Sedimentacija vezljivih lebdečih plavin predstavlja zadnjo (vertikalno) fazo transporta (Liu in sod. 2002; Bungartz in sod. 2001). Nastopi v primeru laminarnega strujanja, ko so negativne vzgonske sile mnogo manjše od teže zrna, zmanjšane za statični vzgon (Mikoš 2000). Kosmi se ponavadi, kljub manjši gostoti, zaradi velikosti usedajo znatno hitreje kot posamični delci gline oziroma melja (Nakagawa in Zhang 2004; Kranenburg 1999; Erosion, transport ... 2008). Zaradi razlik v hitrosti usedanja posameznih delcev in kosmov je splošna slika sedimentacije odvisna od pogostosti nastajanja slednjih. V osnovi se ločuje dve vrsti sedimentacije: popolno in delno. Pri popolni se odložijo vsi delci in kosmi, pri delni pa lahko pride le do usedanja posameznih (obstojnejših) kosmov, medtem ko ostali razpadejo ali pa takoj ponovno preidejo v suspenzijo (Cohesive sediment transport 2008). Ob popolni sedimentaciji se začne zaključna faza usedanja - konsolidacija.

Slika 11: Pomembnejši procesi v okviru transporta in sedimentacije vezljivih lebdečih plavin Figure 11: Important processes of the transport and sedimentation of suspended (wash) load
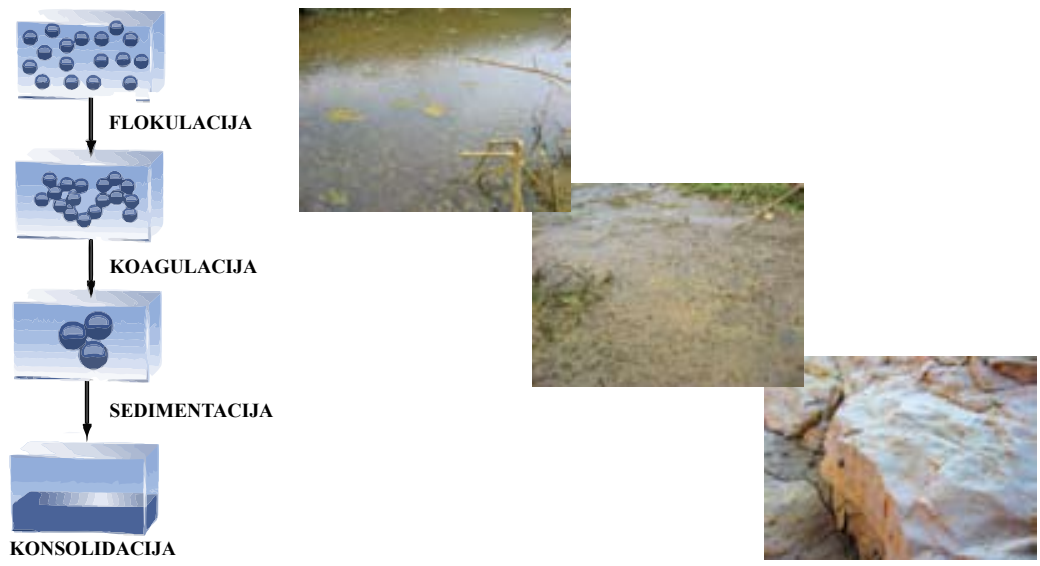

Vir/Source: Colloidal stability 2008; foto/Photo: L. Černuta

\subsection{Vpliv vegetacije na meandrotvorne procese}

Vplivi vegetacije na meandrotvorne procese in posledično na morfološko izoblikovanost vodotokov so odvisni predvsem od tipa vegetacije (drevje, grmovje, trava, alge), lastnosti gradiva brežin ter od geometrije rečnega korita (brežin). Najizrazitejši vplivi so v primeru manjših vodotokov z relativno majhno strugotvorno širino. Obrežna vegetacija vpliva tako na značilnosti vodnega toka $v$ strugi kot tudi na stabilnost brežin oziroma erodibilnost rečnega gradiva.

Vegetacija, predvsem drevesna, ščiti brežine pred erozijo tekoče vode, saj zmanjšuje hitrosti vodnega toka in pretočne sposobnosti rečnega korita. Kljub temu da lahko nekoliko poveča turbulentnost vodnega toka, pa ima velik vpliv predvsem na zmanjšanje obrežnih hitrosti vodnega toka (Thorne 1997). Vegetacija kot sestavni del brežin pogosto pozitivno (sta- 
bilizacijsko) vpliva na mehanske lastnosti naplavin - zmanjšuje njihovo erodibilnost in povečuje stabilnost brežin. Poleg stabilizacijskih učinkov pa mnogi avtorji omenjajo tudi nasprotna opažanja - neposredni vplivi predvsem drevesne vegetacije in njihovih koreninskih sistemov so lahko tudi destabilizacijski. Terenski ogledi v okviru te raziskave omenjene navedbe potrjujejo, zatorej je pri določanju vloge vegetacije, ki jo ta ima na meandrotvorne procese in morfološko preobrazbo vodotokov, potrebna skrajna pazljivost.

\section{MEANDRI DOBRAVKE NA RADENSKEM POLJU}

\section{I. Glavne fizičnogeografske značilnosti preučevanega območja}

Radensko polje je s 4 km² najmanjše kraško polje v Sloveniji (Meze 1977). Na dno polja z nadmorskimi višinami med 318 in $326 \mathrm{~m}$ se stekajo vode večjega dela Grosupeljske kotline, Škocjanskega podolja in povirja Rašice (Lampič in Smrekar 1997). Porečje GrosupeljščiceDobravke se začenja v povirju Velikega potoka in Brega pod hribom Kožereja (707 m) na višini med 650-700 m in je del porečja reke Krke, za katero je značilen dinarski dežnosnežni režim. Od Grosupljega navzdol teče Grosupeljščica po široki naplavni ravnici, ki se južno od naselja razširi v Grosupeljsko polje. Grosupeljščica se preimenuje v Dobravko po sotočju s Podlomščico tik preden priteče na Radensko polje (Gams 2004; Peterlin 2002).

Območje Radenskega polja oziroma njegovo obrobje je iz karbonatnih (jurskih in triasnih) kamnin. Podobna kot sestava obrobja polja je najverjetneje tudi živoskalna sestava dna (Meze 1977). Kotanja Radenskega polja je najverjetneje nastala na prehodu iz pliocena v pleistocen, ko so se posamezni deli ob različnih prelomnih sistemih vertikalno premaknili. Novonastalo kotanjo so vode začele zasipavati, povečini s karbonatnim prodom. Poleg kamninskega drobirja je bilo nanešenega še mnogo drugega gradiva. Prihajalo je do zamašitev odvodnih kanalov ter posledično do večjih poplav in ojezeritev. V mirni jezerski vodi so se odlagali melj, glina in organski ostanki (Culiberg in Dozet 2007).

Delež glinene frakcije se spreminja tako horizontalno kot vertikalno. Poleg spreminjajočega deleža glinene frakcije se spreminja tudi debelina oziroma globina glinene plasti. Po ugotovitvah Culibergove in Dozeta (2007) in po navedbi Mezeta (1981) znaša ta nekje med 5 in $10 \mathrm{~m}$. Debelejši nanosi $(8-10 \mathrm{~m})$ so na vzhodnem, plitvejši $(5-6 \mathrm{~m})$ na zahodnem delu polja, najplitvejši pa na severozahodu. To dejstvo je posledica razlike v višini živoskalne podlage dna polja, nastale zaradi vzdolžnega preloma, ki poteka čez polje v dinarski smeri. Živoskalna podlaga je namreč na zahodu višje kot v vzhodnem delu polja. Temu dejavniku sledi tudi nagnjenost poplavne ravnice proti JV oziroma VJV (Meze 1977; 1981).

Poplave, ki lahko segajo vse do nadmorske višine $326 \mathrm{~m}$ (ob katastrofalnih poplavah pa celo do $330 \mathrm{~m}$ ), deli Meze po trajanju in obsegu na pogoste redne, pogoste srednje in t.i. maksimalne poplave (Meze 1981). Njihov obseg na območju ožje poplavne ravnice Dobravke je prikazan na sliki 12.

Pogoste redne poplave so prisotne okoli pol leta. Pogoste srednje poplave, katerih pogostost in intenzivnost je narasla predvsem po regulacijah Grosupeljščice na Grosupeljskem polju, se pojavljajo večkrat letno, najpogosteje v hladni polovici leta. Podobno velja za t.i. maksimalne poplave, ob katerih je Radensko polje skoraj v celoti poplavljeno (Meze 1981). 
Slika 12: Vrste poplav na severnem delu Radenskega polja

Figure 12: Types of floods in the northern part of the Radensko polje

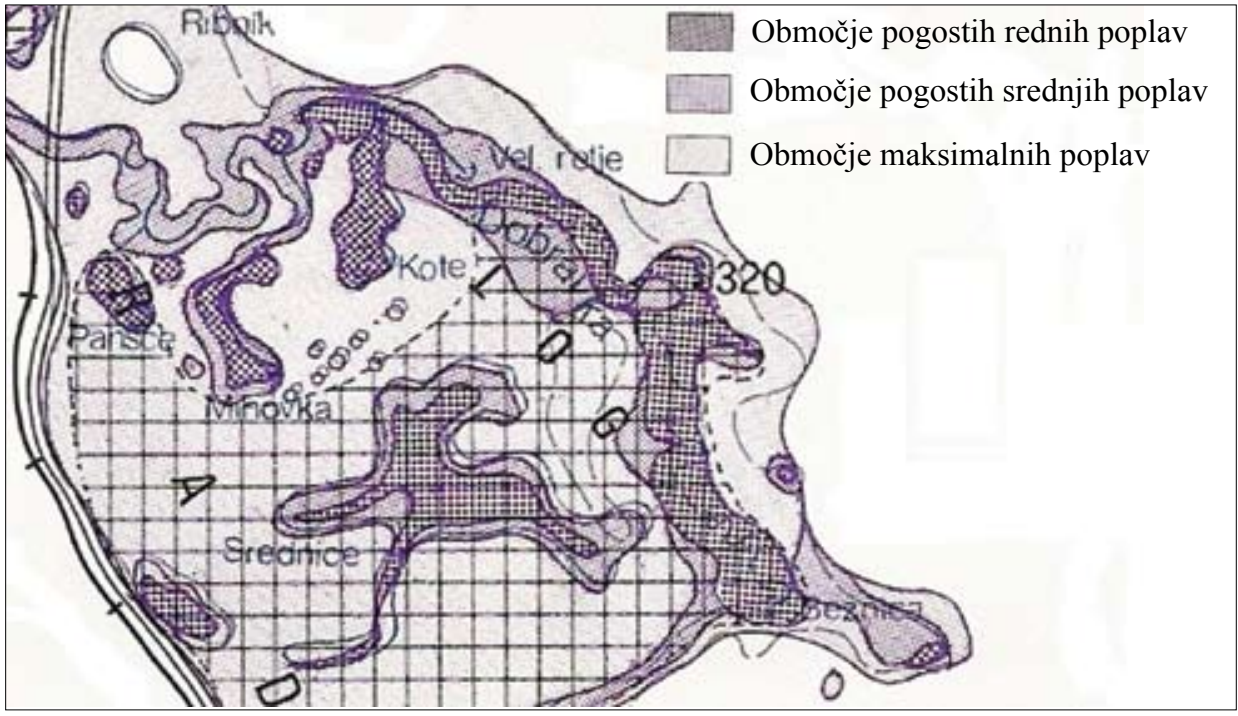

Vir/Source: Meze 1981

\subsection{Recentni meandrotvorni procesi in njihova prostorsko-časovna razporeditev}

Preučevano območje obsega ožjo naplavno ravnico Dobravke med mostom na cesti Malo Mlačevo-Velika Račna in ponorom Beznica. Na osnovi prostorske razporeditve meandrov in poplavnega režima je bilo obravnavano območje razdeljeno na tri podobmočja.

Obstoječa tlorisna usmeritev Dobravke, ki je posledica inicialne prostorske tlorisne usmeritve, je v prvi vrsti odvisna od ('mikro' in 'makro') ekspozicije dna polja. $\mathrm{K}$ modifikaciji (inicialne) tlorisne usmeritve Dobravke so v veliki meri pripomogle tudi lokacije (bližnjih) večjih ponorov oziroma estavel (Veliko retje, Kote in Beznica). Pomembno vlogo pri (inicialni) tlorisni izoblikovanosti Dobravke pa je v veliki meri imel tudi sklenjen obod Radenskega polja, ki je kot tak omejeval 'neomejen' tlorisni razvoj Dobravke.

Vloga zgoraj naštetih dejavnikov se kaže v obstoječi tlorisni izoblikovanosti Dobravke, ki se precej razlikuje od 'idealne' harmonično trigonometrirane izoblikovanosti. Poleg tega imajo prav vsi trije odseki tako visoko sinusoidnost, ki se brez reliefnih 'anomalij' ne bi mogla razviti. Vrednosti maksimalnih odklonskih kotov, potrebnih za nastanek tako razvitih meandrov, namreč presegajo 'brezanomalijsko' mejo $\left(90^{\circ}\right)$. Za nastanek tako sinusoidne struge so torej pomembne reliefne 'anomalije', ki generirajo parcialne tlorisne usmeritve vodotoka. Te se od osnovne povprečne tlorisne usmeritve odseka močno razlikujejo, povzročajo t.i. sekundarno sinusoidnost. 
Slika 13: Preučevano območje, razdeljeno na podobmočja (od zahoda proti vzhodu): območje glavne struge, območje Kot in območje podaljšane struge

Figure 13: Studied area, divided into sub-areas (from west to east): the area of Dobravka's main channel, the Kote area and the area of Dobravka's prolonged channel

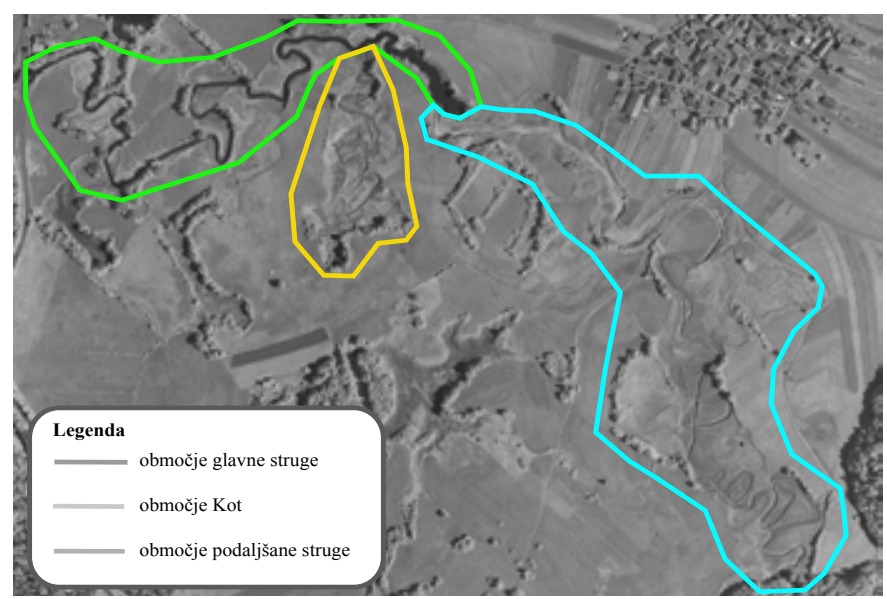

Vir podlage/Source: Ministrstvo za kmetijstvo, gozdarstvo in prehrano-GERK 2008

Slika 14: Osnovna povprečna tlorisna usmeritev (dolga puščica), parcialna tlorisna usmeritev (kratke puščice), sekundarna sinusoidnost (ukrivljena puščica) in antropogeno 'prerezani' meandri (pike) glavne struge Dobravke

Figure 14: The basic planform direction (long arrow), partial planform direction (short arrows), secondary sinuosity (curved arrow) and man-made meander cut-offs (dots) of the stream Dobravka main channel

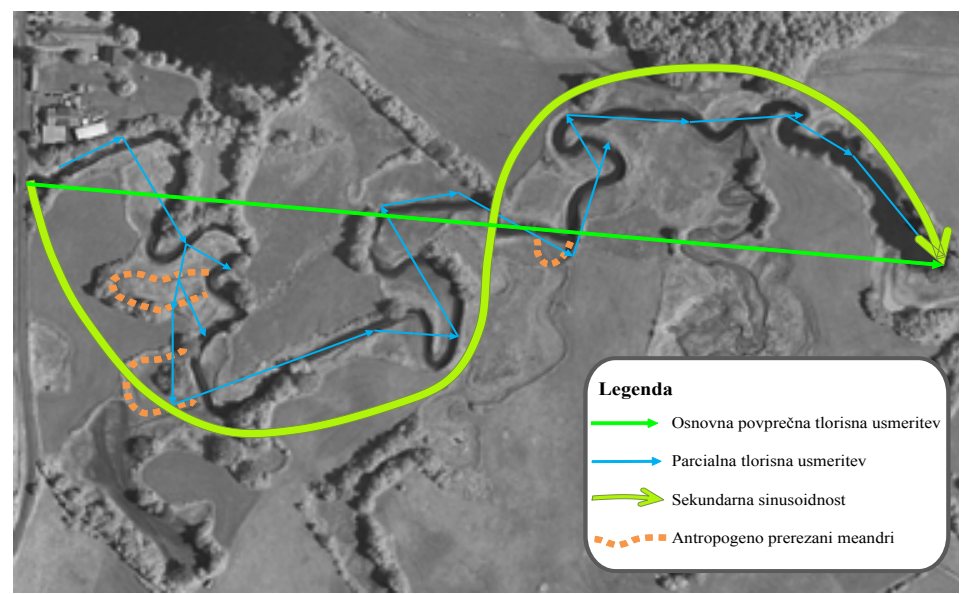

Vir podlage/Source: Ministrstvo za kmetijstvo, gozdarstvo in prehrano-GERK 2008 
Za meandrirajoč odsek glavne struge Dobravke bi se lahko reklo, da ga izmed vseh treh preučevanih odsekov oblikujejo najbolj 'konvencionalni' strugotvorni procesi. Intenziteta fluviogeomorfnih procesov je ob različnih vodostajih različna. To je sicer povsem običajno, vendar je ta različnost ravno obratna kot v primeru nekraških vodotokov. Intenzivnost fluvialne erozije je namreč največja ob relativno majhnih pretokih (nizkem vodostaju), ko je piezometer kraške vode pod nivojem Velikega retja, pretok glavne struge Dobravke pa ne presega ponornih zmogljivosti le-tega. Ta zakonitost velja tudi $\mathrm{v}$ primeru ostalih dveh preučenih (pod)območij.

Slika 15: Vpliv piezometričnega nivoja in ponornih zmogljivosti Velikega retja na meandrotvornost (foto: L. Černuta)

Figure 15: Effects (on the meandering processes) caused by piezometric level and sink capacity of the Veliko retje estavelle (photo: L. Černuta)
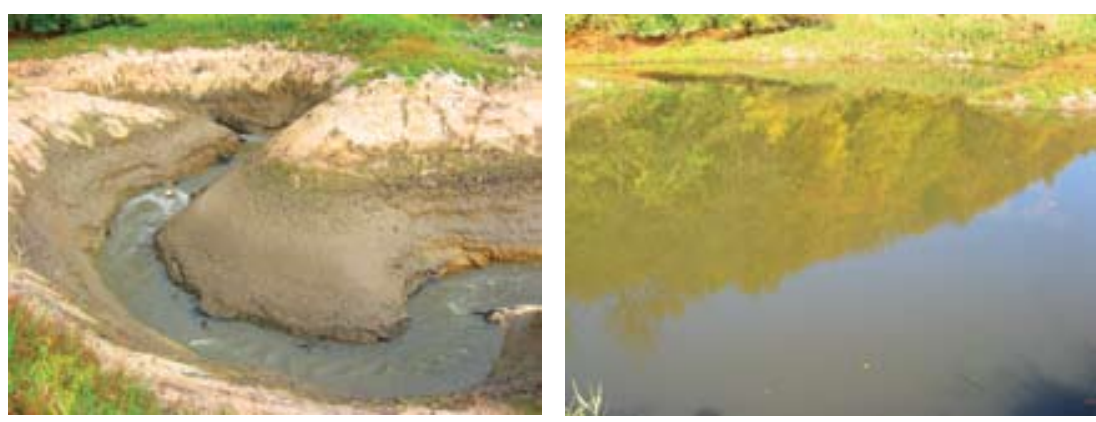

Ker so za časa nizkega vodostaja poleg fluvialne erozije v glavni strugi Dobravke prisotni tudi drugi meandrotvorni procesi, je v tem obdobju (skupna) intenziteta meandrotvornih procesov največja.

Za območje Kot je značilna najdlje trajajoča faza pasivne meandrotvornosti, saj je to območje v celoti preplavljeno že v začetni fazi pogostih rednih poplav. To območje je bilo med obravnavanimi območji najnatančneje preučeno - opravljene so bile nekatere osnovne (v uvodu omenjene) morfološke meritve. Izkazalo se je, da prihaja do zdrsov brežin povečini na območju, kjer so brežine dovolj strme $\left(>55^{\circ}\right)$ in visoke $(>2 \mathrm{~m})$. Izmed subaerialnih procesov so na tem območju kot dejavniki denudacije brežin pomembni samo t.i. vlažnostno pogojeni subaerialni procesi, saj je v hladnejši polovici leta, tj. v času temperaturno pogojenih subaerialnih procesov, območje Kot povečini poplavljeno. Poleg denudacije brežin kot posledice saturacijsko pogojenih subaerialnih procesov je pomembna tudi denudacija, nastala zaradi aridno pogojenih subaerialnih procesov. Nekaj podobnega kot za aridno pogojene subaerialne procese velja tudi za intenzivnost pluvialne erozije, ki dobi posebej pomembno vlogo pri (pre)oblikovanju zelo položnih brežin $\left(<30^{\circ}\right)$ - brežin 'prerezanih' rečnih zavojev, saj v tovrstnem primeru v aktivni fazi meandrotvornosti predstavlja edini strugotvorni proces. Glede na morfološko izoblikovanost brežin v Kotah (povečini plitve in položne) gre sklepati, da ima fluvialna erozija mnogo manjši pomen kot v primeru glavne struge Dobravke. 
Slika 16: Prevladujoči (recentni) meandrotvorni procesi na območju Kot

Figure 16: Dominant (recent) meandering processes on the Kote area

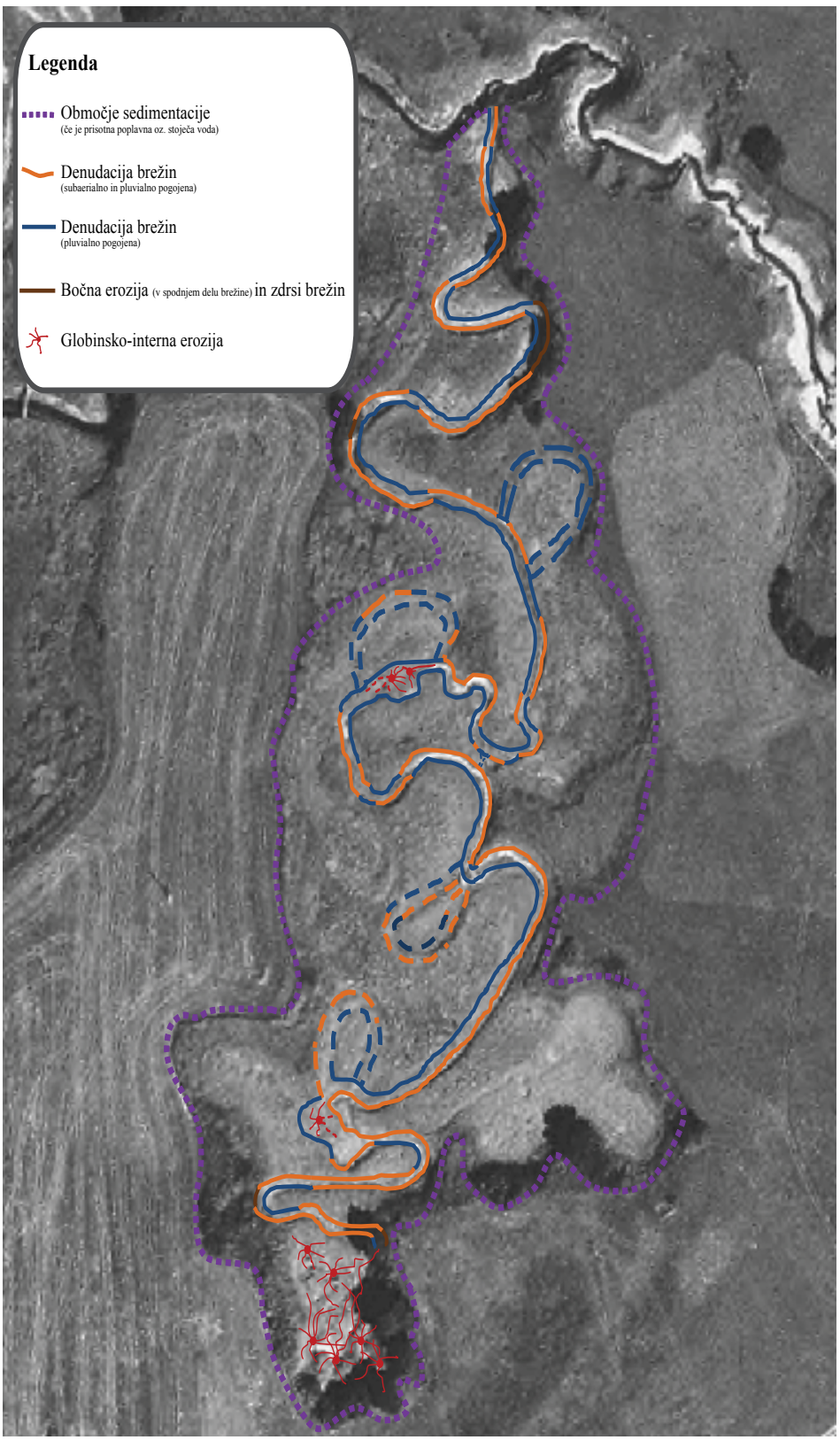

Vir podlage/Source: Ministrstvo za kmetijstvo, gozdarstvo in prehrano-GERK 2008 
Če za glavno strugo velja, da jo preoblikujejo najbolj 'konvencionalni' meandrotvorni procesi, pa je v primeru podaljšane struge Dobravke ravno nasprotno, saj je to (pod)območje največ časa brez vode. Subaerialno pogojena denudacija rečnih brežin je, predvsem v drugi polovici območja podaljšane struge, na svojem pomenu še dodatno pridobila $\mathrm{z}$ regulacijo $\mathrm{v}$ osrednjem delu odseka.

Slika 17: Regulacija (označeno območje) podaljšane struge Dobravke Figure 17: Regulation (marked area) of Dobravka's prolonged (meandering) channel

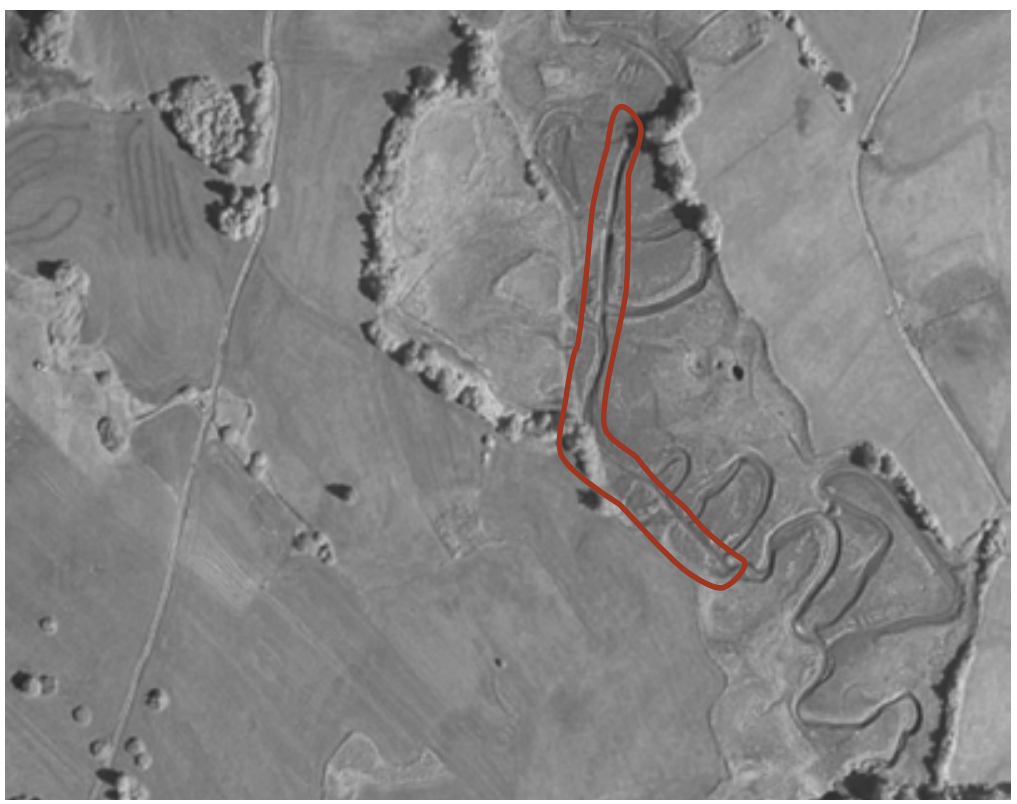

Vir podlage/Source: Ministrstvo za kmetijstvo, gozdarstvo in prehrano-GERK 2008

Antropogeni preboj meandrov je namreč povzročil dodatno izolacijo meandrov pred že tako redko in manj intenzivno fluvialno erozijo. Na tem delu rečnega odseka je tako fluvialno aktivna samo antropogeno vzpostavljena struga, ostala naravno izoblikovana rečna korita pa se v pretežni meri preoblikujejo pod vplivom subaerialno/pluvialno pogojene denudacije. Razlika v prevladujočih meandrotvornih procesih se vidi že na prvi pogled, saj ima antropogeno izravnana struga v povprečju precej bolj strme brežine kot opuščena (fluvialno neaktivna) rečna korita.

Za meandrotvorne procese Dobravke je značilna t.i. prostorsko-časovna conacija, ki je odvisna od stopnje preplavljenosti območja. V okviru prostorske conacije prihaja do vertikalne in horizontalne conacije (slika 19). Pri prvi gre za sočasno različnost meandrotvornih procesov na brežini, pri drugi pa za sočasno različnost meandrotvornih procesov na območju naplavne ravnice. 
Slika 18: Antropogeno vzpostavljena struga in njen prečni prerez (foto: L. Černuta) Figure 18: Man-made channel and its cross-section (photo: L. Černuta)
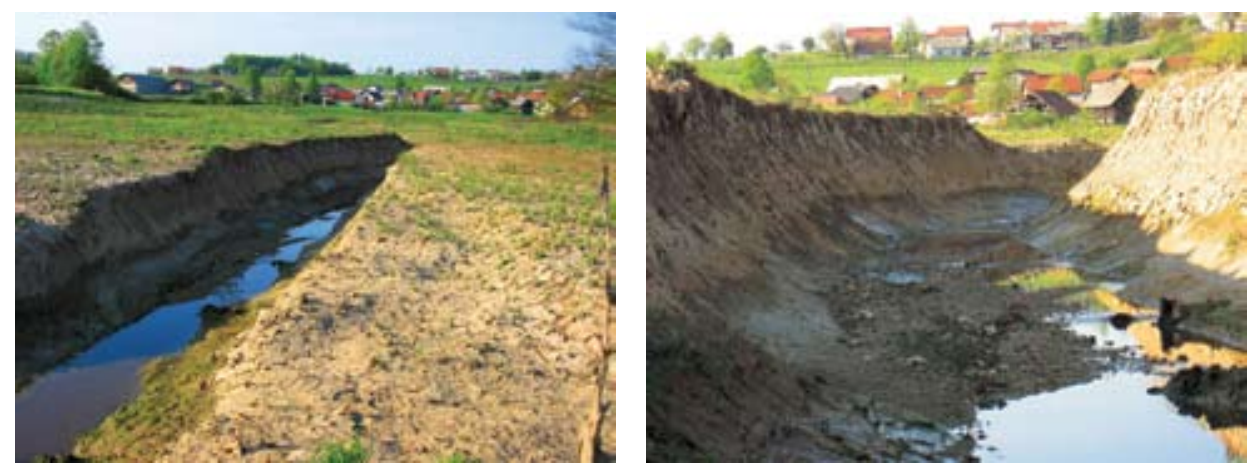

$\mathrm{V}$ primeru časovne conacije meandrotvornih procesov (časovna spremenljivost meandrotvornih procesov znotraj istega območja) pa prihaja v odvisnosti od časovne amplitude do vzajemnosti ali diskretnosti med meandrotvornimi procesi. Nekateri meandrotvorni procesi lahko delujejo sočasno, drugi pa strogo (časovno) ločeno. Primer časovno ločenih meandrotvornih procesov prikazuje slika 20. Medtem ko aridno pogojeni subaerialni procesi potekajo zgolj v sušnem obdobju, se sedimentacija odvija le za časa poplav - stoječih voda.

Slika 19: Vertikalna (levo) in horizontalna (desno) prostorska conacija meandrotvornih procesov Figure 19: Vertical (left) and horizontal (right) spatial zonation of meandering processes
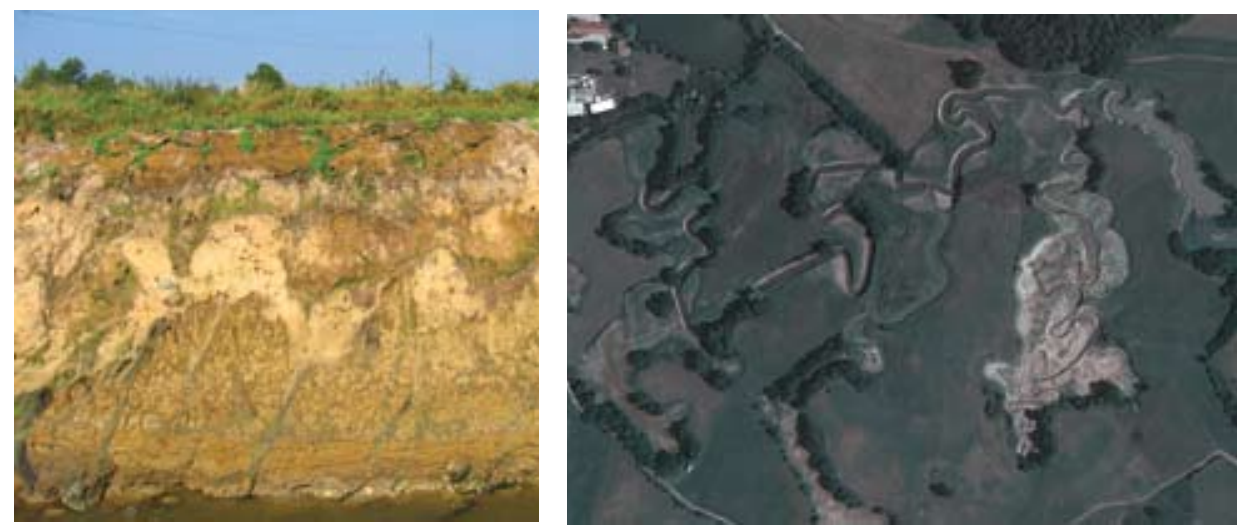

Vira/Sources: foto/Photo: L. Černuta; Ministrstvo za kmetijstvo, gozdarstvo in prehrano-GERK 2008 
Slika 20: Primer diskretnosti meandrotvornih procesov (levo: obdobje prevlade aridno pogojenih subaerialnih procesov; desno: obdobje prevlade sedimentacije)

Figure 20: An example of meandering processes discretion (left: period of subaerial processes (caused by drying) dominance; right: period of sedimentation dominance)
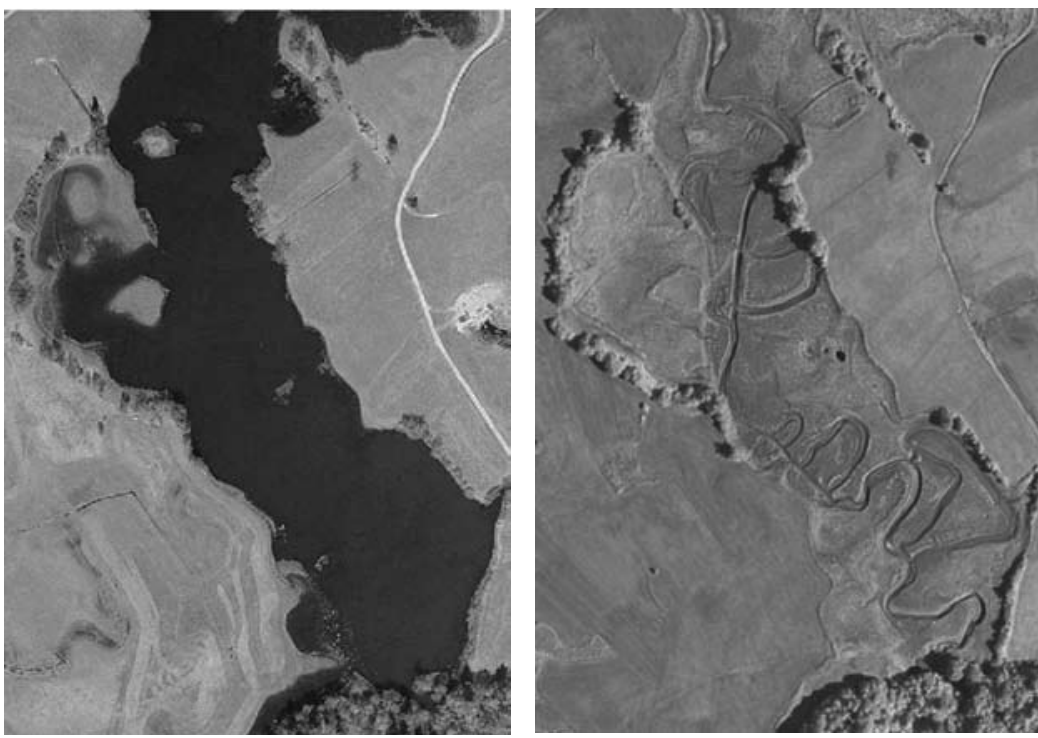

Vir/Source: Ministrstvo za kmetijstvo, gozdarstvo in prehrano - GERK 2008

\section{SKLEP}

Meandrirajoča struga je najobičajnejša tlorisna oblika nizkoenergijskih vodotokov. Nizkoenergijski vodotoki bi teoretično sicer lahko bili izravnani, vendar takšni ne bi ostali dolgo. Za trajnejšo izravnanost bi morali biti izpolnjeni (idealni) pogoji stalne in popolne morfološke simetrije (npr. simetrija v prečnem prerezu) in hidravlično-sedimentološke konstantnosti. Ker takih pogojev v naravi ni, pride na prosto tekočih vodotokih nujno do raznovrstnih morfoloških sprememb, ki se s tlorisnega vidika kažejo (tudi) kot rečni meandri. Nizkoenergijski vodotoki so torej že po svoji 'naravi' podvrženi meandriranju.

Rečni meandri na kraških poljih so dinamične tvorbe, ki se pod vplivom različnih meandrotvornih procesov stalno spreminjajo. Na meandrotvorne procese vplivajo raznovrstni (povečini fizičnogeografski) dejavniki, tako tisti na kraškem polju kot tudi na širšem območju (porečju) izven polja. Gre predvsem za dejavnike, ki vplivajo na dotok rečne vode na območje naplavne ravnice. Najpomembnejše fizičnogeografske značilnosti zalednega območja kraškega polja so s tega vidika geomorfološke in geološke ter klimatske in vegetacijske značilnosti. Fizičnogeografske značilnosti kraškega polja, skupaj s fizičnogeografskimi značilnosti zalednega območja, vplivajo na hidrogeografske značilnosti polja. Od teh pa zavisi dinamika in prostorsko-časovna variabilnost meandrotvornih procesov, saj je ta odvisna predvsem od periodičnosti in obsega poplavnih voda. 
Meandrotvorni procesi tvorijo tri temeljne sklope: procese odnašanja, transport in sedimentacijo. Medtem ko sta slednja dva procesa fluvialno pogojena, so procesi odnašanja nekoliko kompleksnejši. Poleg fluvialne erozije namreč potekajo tudi procesi denudacije rečnih brežin. Pri fluvialni eroziji gre za odnašanje naplavinskega gradiva vzdolž struge, pri denudaciji pa prečno na strugo oziroma njeno brežino. Oba sklopa procesov sicer delujeta vzajemno in sta neločljivo povezana, vendar pa je denudacija pomembna predvsem zaradi dejstva, da do nje pride pogosto tudi ob razmerah, ko v strugi ni (tekoče rečne) vode.

$\mathrm{Na}$ osnovi rezultatov preučevanja lahko zaključimo, da zastavljene hipoteze, ki pravi, da so rečni meandri geomorfne oblike, nastale kot posledica delovanja tekoče rečne vode, ni mogoče v celoti potrditi. Fluviogeomorfne procese namreč modificira denudacija rečnih brežin, ki pogosto ni neposredno fluvialno pogojena. Kljub temu dejstvu pa mora za aktivno preoblikovanje rečnih meandrov fluvialna erozija prevladovati nad vsemi ostalimi meandrotvornimi procesi. Njena intenziteta mora biti vsaj tolikšna, kolikor znaša intenziteta denudacije rečnih brežin in sedimentacija plavin skupaj. V nasprotnem primeru pride do pasivne meandrotvornosti, ki preprečuje nadaljnji aktivni razvoj meandrov.

Za pravilnejše tolmačenje nastanka rečnih meandrov na kraških poljih bodo v prihodnje potrebna podrobnejša teoretična preučevanja meandrotvornih procesov, še pomembnejše pa bodo bolj podrobne terenske raziskave in raziskave v laboratorijskih kanalih, ki bodo morale temeljiti na natančnejših in dolgotrajnejših meritvah. Za pravilnejše tolmačenje geneze rečnih meandrov je namreč nujna kvantifikacija meandrotvornih procesov.

\section{Viri in literatura}

Adam, J. A. 2006: Mathematics in nature: modeling patterns in the natural world. New York. Aggregation, flocculation and coagulation. Medmrežje: http://www.malvern.co.kr (12.6.2008). Ahnert, F. 1996: Introduction to geomorphology. London.

Alvarez, A. 2005: Channel planform dynamics of an alluvial tropical river. Medmrežje: http://txspace.tamu.edu (15.12.2006).

Beechie, J. T., Liermann, M., Pollock, M. M., Baker, S., Davies, J. 2006: Channel pattern and river-floodplain dynamics in forested mountain river systems. Medmrežje: http://www. sciencedirect.com (25.8.2007).

Bizjak, A. 2003: Sintezni postopek ocenjevanja hidromorfološkega stanja rečnih koridorjev, razvit z analizo stanja na reki Dragonji. Doktorska disertacija, Fakulteta za gradbeništvo in geodezijo Univerze v Ljubljani. Ljubljana.

Bungartz, H., Krüger, A., Engelhardt, C. 2001: The impact of particle aggregation on suspended sediment transport and deposition in a lowland river. Medmrežje: http://www. igb-berlin.de (25.9.2008).

Chorley, R. J., Schumm, S. A., Sugden, D. E. 1984: Geomorphology. London.

Cohesive sediment transport. Medmrežje: http://www.usbr.gov (9.9.2008).

Colloidal stability. Medmrežje: http://www.silver-colloids.com (12.9.2008).

Couper, P. 2003: Effects of silt-clay content on the susceptibility of river banks to subaerial erosion. Medmrežje: http://www.sciencedirect.com (21.1.2008). 
Culiberg, M., Dozet, S. 2007: Palynologic and lithostratigraphic research of lacustrine, marsh and fluvial Quaternary deposits in Rašica dolina and Mišja dolina, and on Radensko polje. Hacquetia 6, 1. Ljubljana.

Černuta, L. 2009: Rečni meandri na kraških poljih. Diplomsko delo, Oddelek za geografijo Filozofske fakultete Univerze v Ljubljani. Ljubljana.

Earth Science World Image Bank. Medmrežje: http://www.earthscienceworld.org (12.8.2008).

Erosion, transport and deposition of cohesive sediments. Medmrežje: http://www.usace. army.mil (12.8.2008).

Gams, I. 2004: Kras v Sloveniji v prostoru in času. Ljubljana.

Geografija. Učila International. Tržič 2001.

Hrovat, A. 1953: Kraška ilovica: njene značilnosti in vpliv na zgradbe. Ljubljana.

Julian, J. P., Torres, R.: Hydraulic erosion of cohesive riverbanks. Medmrežje: http://www. unc.edu (1.3.2008).

Julien, P. Y. 2002: River mechanics. Cambridge.

Knighton, D. 1998: Fluvial forms and processes. New York.

Kranenburg, C. 1999: Effects of floc strength on viscosity and deposition of cohesive sediment suspensions. Medmrežje: http://www.sciencedirect.com (22.8.2008).

Krishnappan, B. G., Marsalek, J. 2002: Modelling of flocculation and transport of cohesive sediment from an on-stream stormwater detention pond. Medmrežje: http://www.sciencedirect.com (25.8.2008).

Lampič, B., Smrekar, A. 1997: Geološke, geomorfološke in hidrološke značilnosti Radenskega polja. Elaborat, Inštitut za geografijo. Ljubljana.

Langbein, W. B., Leopold, L. B. 1966: River meanders-theory of minimum variance. Medmrežje: http://eps.berkeley.edu (1.2.2007).

Leopold, L. B., Wolman, M. G. 1957: River channel patterns: braided, meandering and straight. Medmrežje: http://eps.berkeley.edu (1.2.2007).

Likar, A. 1999: Meandri. Presek 26, 6. Ljubljana.

Liu, W.-C., Hsu, M.-H., Kuo, A. Y. 2002: Modelling of hydrodynamics and cohesive sediment transport in Tanshui River estuarine system, Taiwan. Medmrežje: http://www. sciencedirect.com (25.8.2008).

Lovrenčak, F. 1994: Pedogeografija. Ljubljana.

Meandering River Wampool. Medmrežje: http://www.geograph.org.uk (11.11.2007).

Meze, D. 1977: Prispevek k hidrologiji Radenskega polja. Geografski vestnik 49. Ljubljana.

Meze, D. 1981: Poplavna področja v Grosupeljski kotlini. Geografski zbornik 20, 1. Ljubljana.

Mikoš, M. 2000: Urejanje vodotokov. Skripta, Fakulteta za gradbeništvo in geodezijo, Katedra za splošno hidrotehniko. Ljubljana.

Mikoš, M., Batistič, P., Đurović, B., Humar, N., Janža, M., Komac, M., Petje, U., Ribičič, M., Vilfan, M. 2004: Metodologija za določanje ogroženih območij in način razvrščanja zemljišč v razrede ogroženosti zaradi zemeljskih plazov. Končno poročilo, Fakulteta za gradbeništvo in geodezijo, Katedra za splošno hidrotehniko, Ljubljana.

Mikoš, M., Kranjc, A., Matičič, B., Müller, J., Rakovec, J., Roš, M., Veselič, M., Brilly, M. 2002: Hidrološko izrazje. Acta hydrotehnica 20, 32. Ljubljana. 
Ministrstvo za kmetijstvo, gozdarstvo in prehrano - GERK. Medmrežje: http://rkg.gov.si (30.11.2008).

Nakagawa, H., Zhang, H. 2004: Modelling of total sediment load transport in alluvial rivers. Medmrežje: http://www.dpri.kyoto-u.ac.jp (25.6.2008).

Natek, K. 2003: Geomorfologija. Študijsko gradivo za predmet Geomorfologija. Oddelek za geografijo, Filozofska fakulteta Univerze v Ljubljani. Ljubljana.

Natek, K. 2005: Poplavna območja v Sloveniji. Geografski obzornik 52, 1. Ljubljana.

Peterlin, S. 2002: Radensko polje: bodoči krajinski park. Proteus 65, 3. Ljubljana.

Petts, G. E., Amoros, C. (ur.) 1996: Fluvial hydrosystems. London.

Plazl, I.: Tok tekočin in hidrodinamične operacije. Medmrežje: http://www.fkkt.uni-lj.si (23.8.2008).

Repnik, P. 2006: Prispevek k hidromorfološki tipizaciji slovenskih vodotokov. Diplomsko delo, Fakulteta za gradbeništvo in geodezijo Univerze v Ljubljani. Ljubljana.

Ritter, D. F., Kochel, R. C., Miller, J. R. 1995: Process geomorphology. Dubuque.

Robert, A. 2003: River processes. London.

Rosgen, D. 1994: A classification of natural rivers. Medmrežje: http://www.wildlandhydrology. com/ (29.11.2007).

Rumore bianco. Medmrežje: http/www.sentieriselvaggi.it (12.10.2009).

Rusjan, S., Mikoš, M. 2006: Dinamika premeščanja lebdečih plavin v porečjih. Acta hydrotehnica 24, 40. Ljubljana.

Steinman, F. 1999: Hidravlika. Ljubljana.

Suhadolc, M., Rupreht, J., Zupan, M. 2006: Študijsko gradivo za vaje iz pedologije: za strokovni študij agronomije. Biotehniška fakulteta, Oddelek za agronomijo. Ljubljana.

Thorne, C. R. (ur.) 1997: Applied fluvial geomorphology for river engineering and management. Chichester.

Wynn, T. M., Henderson, M. B., Vaughan, D. H. 2006: Changes in streambank erodibility and critical shear stress due to subaerial processes along a headwater stream, southwestern Virginia, USA. Medmrežje: http://www.sciencedirect.com (25.6.2008).

\section{RIVER MEANDERS ON POLJES}

\section{Summary}

A meandering channel is the most common planform of low-energy streams. In theory, lowenergy streams could be straight but this would be only temporarily. Permanent straightness would require (ideal) permanent and perfect conditions of morphological symmetry (e.g. cross-sectional symmetry) as well as hydraulic-sedimentary constancy. Since it is clear that such conditions do not exist in nature, various morphological changes appear in free-flowing streams. In terms of planform morphology they are known as meanders. Low-energy streams are in their essence meander-prone.

River meanders on poljes are dynamic forms. They are constantly modified due to various meandering processes which depend on different (physical)-geographical factors of polje and its hinterland. Most of these factors are influenced by the inflow of running (river) water 
onto the floodplain area. From this point of view, the most important (physical)-geographical characteristics of polje and its hinterland are its morphological, geological, climatic and vegetation features. Physical-geographical characteristics of polje (direct factors) influence its hydrogeographical characteristics which dictate the meandering processes. Dynamics and space-time variability of the meandering processes are led by the periodicity and the extent of flood waters. Periodical flooding, which is typical of most poljes, causes a mixture of studied meandering processes.

Three main groups of meandering processes are distinguished: erosion, transportation and sedimentation. While the last two are fluvially conditioned, erosion processes are a bit more complex. Besides fluvial erosion, the denudation of river banks also takes place. In fluvial erosion, alluvial deposits are carried away along the river channel, while denudation works transversely to the channel (river bank). Both groups of processes work mutually, they are inseparably connected. Besides, denudation (subaerially and pluvially conditioned) is also important because it often occurs when there is no running water in the river channel.

The obtained research results cannot fully confirm our hypothesis that river meanders are geomorphic features formed by running (river) water. Fluvial processes (erosion) are namely modified by denudation, which is often not directly fluvially conditioned. In spite of this, fluvial erosion must prevail over all other meandering processes to assure active (re)forming of river meanders. It must be at least as intense as denudation of river banks and sedimentation or the process will lead to a passive phase which prevents active river meanders (re)formation.

For accurate understanding of river meanders formation on poljes, more detailed theoretical studies and research work will be required. Even more important will be detailed field work research and laboratory flume experiments, which will have to be backed by long lasting measurements. The quantification of the meandering processes is required for a better understanding of river meander genesis and their modelling.

(Translated by the author) 